UDC $661.882 .22-14.061+544-971$

\author{
A.V. Dubenko ${ }^{a}$, N.V. Nikolenko ${ }^{a}$, A.B. Velichenko ${ }^{a}$, A.D. Suschinskii ${ }^{b}$
}

\title{
THERMODYNAMIC MODELING OF SULFATE-ACID AND SULFATE-FLUORIDE LEACHING OF TITANIUM
}

\author{
${ }^{a}$ Ukrainian State University of Chemical Technology, Dnipro, Ukraine

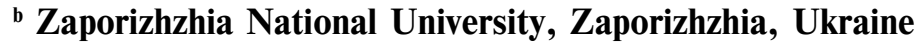

\begin{abstract}
The thermodynamic equilibrium in $\mathrm{TiO}_{2}-\mathrm{SO}_{3}-\mathrm{H}_{2} \mathrm{O}$ and $\mathrm{TiO}_{2}-\mathrm{NaF}-\mathrm{SO}_{3}-\mathrm{H}_{2} \mathrm{O}$ systems is studied. It is shown that rutile can spontaneously dissolve in sulfuric acid solutions. However, rutile is considered as an inert component of the titanium-bearing raw material due to the inhibition of such reactions. The kinetic deceleration of rutile dissolution in sulfuric acid is explained by the lability of Ti(IV) cations and the specific features of the rutile crystal structure. The breaking of $\mathrm{Ti}-\mathrm{O}-\mathrm{Ti}$ bonds without additional deformations of the crystal lattice is suggested to be more beneficial when using smaller anions; thus, fluoride ions can be used to this end. The thermodynamic analysis of sulfate-fluoride leaching of titanium confirms an additional decrease in Gibbs energy values for the dissolution of rutile in sulfuric acid in the presence of fluoride ions. A reaction mechanism is proposed for the interaction of rutile with sulfuric acid. The mechanism includes the stage of substitution of oxygen ions on the rutile surface by fluoride ions and the stage of sulfate-acid decomposition of titanium dioxide in places of «defects» of the rutile surface.
\end{abstract}

Keywords: thermodynamic modeling, sulfuric acid, fluoride ions, altered ilmenite; rutile.

DOI: $10.32434 / 0321-4095-2020-130-3-69-76$

\section{Introduction}

Currently, the global production of titanium dioxide is about 6 million tons per year and its demand grows continuously by an average on $2.5 \%$ per year. The raw material base of titanium placers counts more than 40 deposits in Ukraine. Nowadays, the main raw materials for the industrial production of titanium dioxide are ilmenites from Irshanske and Malyshevske deposits, which are processed by the sulfate-acid method. The mineral raw materials from these deposits are distinguished by their mineralogical compositions and, as a consequence, by their chemical properties. Therefore, materials are characterized by different leaching degrees. Thus, the ilmenite concentrate from Irshanske deposit contains at least $94 \% \mathrm{FeTiO}_{3}$ and it is leached by concentrated sulfuric acid almost completely [1].

The leaching degree of titanium barely reaches $15 \%$ with a leaching process duration of 5 hours for ilmenite from the Malyshevske deposit even when using 90-92\% sulfuric acid solutions [2,3]. The reason for the low leaching degree of this ore is a change in its composition due to the removal and oxidation of bivalent iron with the formation of trivalent iron, which leads to a decrease in $\mathrm{FeTiO}_{3}$ content and an increase in the proportion of pseudorutil $\mathrm{Fe}_{2} \mathrm{Ti}_{3} \mathrm{O}_{9}$ and $\mathrm{TiO}_{2}$ (rutile modification) to $65 \%$. These ores are called «altered ilmenites» or «leukoxenized ilmenites». The leaching with sulfuric acid cannot ensure complete recovery of titanium from this ore due to the chemical inertness of rutile with respect to concentrated sulfuric acid. The undissolved rutile in the composition of the sludge after processing of ilmenite ores moves into dumps, which leads to the accumulation of waste products in the production area, environmental degradation and losses of the target component (titanium).

In our opinion, the improvement of the technological parameters of the sulfate leaching of titanium from the rutile fraction of altered ilmenites is possible by means of the addition of a fluorinating reagent in the reaction mixture. Direct fluorination of ilmenite ores are described in literature [4,5]. It is shown that fluorination reactions occur by the mechanism of successive substitution of oxygen atoms by fluorine atoms on the surface of ore particles in a wide temperature range (from 298 to $1800 \mathrm{~K}$ ). A method for indirect fluorination of ilmenites by using 
solutions of hydrogen fluoride has bee also described $[6,7]$. It is interesting to note that fluorination of $\mathrm{TiO}_{2}$ with anhydrous $\mathrm{HF}$ is impossible and the presence of water is necessary for reactions to occur. In our opinion, an explanation of this is possible from the standpoint of the dissociation process of $\mathrm{HF}\left(\mathrm{HF}+\mathrm{H}_{2} \mathrm{O}=\mathrm{H}_{3} \mathrm{O}^{+}+\mathrm{F}^{-}\right)$with the subsequent participation of fluorine ions in the substitution reaction.

A method for indirect fluorination of ilmenites has been suggested that involves the use of saturated aqueous solutions of hydrodifluoride or ammonium fluoride at boiling point $[8,9]$. This fluoride method is considered quite promising not only due to possibility of efficient processing of altered ilmenites, but also from the point of view of recycling of the main components. Its significant disadvantages include a relatively high consumption of a leaching reagent (fluorides are consumed in reactions not only through the interaction with titanium(IV), but also with iron(III)) and a large number of process steps. These disadvantages lead to increased cost of the product as compared with the cost of the product obtained by sulfate-acid leaching method.

We think that the combination of fluoride and sulfate methods will overcome the above-mentioned disadvantages due to possible synergy of the simultaneous interaction of sulfuric and hydrofluoric acids with titanium dioxide, since the main source of titanium losses are associated with the formation of sludge during sulfuric leaching of altered ilmenites. The preliminary experiments with the titanium leaching from altered ilmenite by the sulfate-fluoride method have confirmed this assumption. Sodium fluoride was used as a fluoride precursor. It was found that the fluoride additives sharply accelerate the process of sulfuric dissolution of ilmenite. In our opinion, it is of interest to investigate the mechanism of such a process in order to determine optimal conditions for industrial implementation.

However, it is necessary to evaluate the thermodynamic possibility of chemical transformations in the $\mathrm{TiO}_{2}-\mathrm{SO}_{3}-\mathrm{H}_{2} \mathrm{O}$ and $\mathrm{TiO}_{2}-\mathrm{NaF}-\mathrm{SO}_{3}-\mathrm{H}_{2} \mathrm{O}$ systems. The effectiveness of this approach was demonstrated by us previously [1012]. Thus, this work was aimed at thermodynamic modeling of the reaction of decomposition of rutile by sulfuric acid in the absence and presence of fluoride ion.

\section{Calculations}

Titanium dioxide (the main component of the sludge), $100 \mathrm{wt} . \%$ or $85 \mathrm{wt} \%$ solutions of sulfuric acid and crystalline sodium fluoride (a source of fluoride ions) were considered as initial materials for thermodynamic modeling of the leaching process. Titanium(IV) sulfate and oxysulfate were considered as the main products of the rutile dissolution reaction [13]. It was assumed that the reactants and reaction products are in the form of pure phases, i.e. in their respective standard states. All necessary thermodynamic data for the participants of the chemical transformations were taken from Ivtantermo electronic database (available from: http://www.chem.msu.ru/cgi-bin/tkv.pl?show= welcome.html). Reliability of the data was checked by the correlation-graphical method. The essence of that method is to consider the correlations between the thermodynamic parameters of the external electronic shells of compounds of the same composition and electronic structure. For example, to evaluate the correctness of the enthalpy of titanium oxysulfate formation given in the handbook, the correlations between the standard enthalpies of titanium(IV) and zirconium(IV) oxides, sulfates and oxysulfates were considered. It was established that such a correlation is described by the following linear equation (in $\mathrm{kJ} / \mathrm{mol}$ ):

$$
\Delta \mathrm{H}_{298}^{0}(\mathrm{Zr})=-86.64+1.057 \cdot \Delta \mathrm{H}^{0}{ }_{298}(\mathrm{Ti}) .
$$

The proximity of the correlation coefficient to unity confirms the possibility of assessing the thermodynamic parameters of titanium compounds based on a comparison with similar data for compounds of zirconium, which is an electronic analog of titanium with respect to valence shells. For example, the calculated value of $\Delta \mathrm{H}^{0}{ }_{298}$ for $\mathrm{TiOSO}_{4}$ is $-1569 \mathrm{~kJ} / \mathrm{mol}$ and the reference value is $-1601.6 \mathrm{~kJ} / \mathrm{mol}$.

In addition, the difference in the thermodynamic parameters of $100 \%$ sulfuric acid and its aqueous solutions was taken into account during the calculations. The data for sulfuric acid and its hydrates were taken from literature [14]. The analysis of these data by the correlation-graphical method showed a linear dependence (with a correlation coefficient $\mathrm{R}^{2}=0.9997$ ) between the enthalpy of formation of sulfuric acid solutions and the number of water molecules (n) in the hydrate:

$$
\Delta \mathrm{H}_{298}^{0}\left(\mathrm{H}_{2} \mathrm{SO}_{4} \cdot \mathrm{nH}_{2} \mathrm{O}\right)=-822.62-298.72 \mathrm{n} .
$$

For example, the calculated value of $\Delta \mathrm{H}_{298}^{0}$ for the $\mathrm{H}_{2} \mathrm{SO}_{4} \cdot \mathrm{H}_{2} \mathrm{O}$ hydrate is $-1121 \mathrm{~kJ} / \mathrm{mol}$, and the reference value is $-1127.6 \mathrm{~kJ} / \mathrm{mol}$.

The changes of standard Gibbs energy during chemical transformations were determined by the Temkin-Schwartzman method according to the 
formula:

$$
\Delta \mathrm{G}^{0}=\Delta \mathrm{H}_{298}^{0}-\mathrm{T} \Delta \mathrm{S}_{298}^{0}-\mathrm{T} \int_{298}^{\mathrm{T}} \frac{\mathrm{dT}}{\mathrm{T}^{2}} \int_{298}^{\mathrm{T}} \Delta \mathrm{C}_{\mathrm{p}} \mathrm{dT} .
$$

The change in heat capacity was determined by the equation $\Delta \mathrm{C}_{\mathrm{P}}=\Delta \mathrm{a}+\Delta \mathrm{bT}+\Delta \mathrm{cT}^{-2}$, (here the temperature dependence of heat capacity is written in the form of an interpolation formula $\mathrm{C}_{\mathrm{P}}=\mathrm{a}+\mathrm{bT}+\mathrm{cT}^{-2}$. The last member in the right side of equation for $\Delta \mathrm{G}^{0}$ was calculated by the formula:

$$
\int_{298}^{\mathrm{T}} \frac{\mathrm{dT}}{\mathrm{T}^{2}} \int_{298}^{\mathrm{T}} \Delta \mathrm{C}_{\mathrm{p}} \mathrm{dT}=\Delta \mathrm{aM}_{0}+\Delta \mathrm{bM}_{1}+\Delta \mathrm{cM}_{-2}
$$

where $\mathrm{M}_{0}, \mathrm{M}_{1}$ and $\mathrm{M}_{-2}$ are some coefficients that depend on temperature as follows:

$$
\begin{gathered}
\mathrm{M}_{0}=\ln \frac{\mathrm{T}}{298.16}+\frac{298.16}{\mathrm{~T}}-1 \\
\mathrm{M}_{1}=\frac{1}{2 \mathrm{~T}}(\mathrm{~T}-298.16)^{2} \\
\mathrm{M}_{-2}=\frac{1}{2}\left(\frac{1}{298.16}-\frac{1}{\mathrm{~T}}\right)^{2}
\end{gathered}
$$

\section{Results and discussion}

Thermodynamic model of rutile dissolution in sulfuric acid

The composition of titanium sulfates does not remain constant in course of the process of sulfateacid leaching of altered ilmenites [13]. The salt $\mathrm{Ti}\left(\mathrm{SO}_{4}\right)_{2}$ is a dominant form at the first stage when the temperature of the reaction medium reaches $200^{\circ} \mathrm{C}$. A decrease in the acid concentration and a decrease in temperature from the moment of a sludge formation (solidification of the reaction mixture) during the chemical reaction lead to the formation of the $\mathrm{TiOSO}_{4}$ salt. This salt also crystallizes when the titanium content in the reaction medium increases. This salt does not contain any crystallization water, which is well explained by the following fact: the water that is not evaporated before sludge solidification is bound into relatively strong sulfuric acid hydrates $\mathrm{H}_{2} \mathrm{SO}_{4} \cdot \mathrm{nH}_{2} \mathrm{O}$.

Since water cannot be considered as a pure phase in concentrated solutions of sulfuric acid (i.e. in the standard state) due to the formation of $\mathrm{H}_{2} \mathrm{SO}_{4} \cdot \mathrm{nH}_{2} \mathrm{O}$, the reactions of rutile dissolution in sulfuric acid were written taking into account the formation of sulfuric acid hydrates. Evidently, $n=0$ and $\mathrm{n}=1$ for $100 \%$ and $85 \%$ sulfuric acid, respectively. Therefore, we considered the dissolution reaction of rutile in sulfuric acid for two particular cases when two acid hydrates are formed (with $n=1$ and $n=2$ ):

a) for $100 \%$ sulfuric acid:

$\mathrm{TiO}_{2}+4 \mathrm{H}_{2} \mathrm{SO}_{4}=\mathrm{Ti}\left(\mathrm{SO}_{4}\right)_{2}+2\left(\mathrm{H}_{2} \mathrm{SO}_{4} \cdot \mathrm{H}_{2} \mathrm{O}\right)$,

$\mathrm{TiO}_{2}+2 \mathrm{H}_{2} \mathrm{SO}_{4}=\mathrm{TiOSO}_{4}+\mathrm{H}_{2} \mathrm{SO}_{4} \cdot \mathrm{H}_{2} \mathrm{O}$,

b) for $85 \%$ sulfuric acid:

$\mathrm{TiO}_{2}+6\left(\mathrm{H}_{2} \mathrm{SO}_{4} \cdot \mathrm{H}_{2} \mathrm{O}\right)=\mathrm{Ti}\left(\mathrm{SO}_{4}\right)_{2}+4\left(\mathrm{H}_{2} \mathrm{SO}_{4} \cdot 2 \mathrm{H}_{2} \mathrm{O}\right)$,

$\mathrm{TiO}_{2}+3\left(\mathrm{H}_{2} \mathrm{SO}_{4} \cdot \mathrm{H}_{2} \mathrm{O}\right)=\mathrm{TiOSO}_{4}+2\left(\mathrm{H}_{2} \mathrm{SO}_{4} \cdot 2 \mathrm{H}_{2} \mathrm{O}\right)$.

Table 1 shows the calculation results for $\Delta \mathrm{H}^{0}{ }_{298}$, $\Delta \mathrm{S}^{0}{ }_{298}, \Delta \mathrm{G}^{0}{ }_{298}$ and the coefficients $\Delta \mathrm{a}, \Delta \mathrm{b}$ and $\Delta \mathrm{c}$ of the heat capacity change for reactions $(1)-(4)$.

The highest decrease in the standard Gibbs energy is observed for the reaction of $\mathrm{Ti}\left(\mathrm{SO}_{4}\right)_{2}$ formation resulted from dissolution of rutile in $100 \%$ sulfuric acid. The standard formation energy of $\mathrm{Ti}\left(\mathrm{SO}_{4}\right)_{2}$ decreases by almost $50 \mathrm{~kJ} / \mathrm{mol}$ in $85 \%$ sulfuric acid. However, this salt is the most thermodynamically stable sulfate compound of titanium(IV) even in this case. The dissolution of titanium dioxide in sulfuric acid with the formation of $\mathrm{TiOSO}_{4}$ is also characterized by negative values of the standard Gibbs energy (Eqs. (2) and (4)).

The results of the calculation of temperature dependences for the change in the standard Gibbs energy of reactions (1)-(4) are presented in Fig. 1. The calculations were carried out for the temperature

\begin{tabular}{|c|c|c|c|c|c|c|}
\hline Reaction & $\begin{array}{l}\Delta \mathrm{H}^{0}{ }_{298}, \\
\mathrm{~kJ} / \mathrm{mol}\end{array}$ & $\begin{array}{c}\Delta \mathrm{S}^{0}{ }_{298} \\
\mathrm{~kJ} / \mathrm{mol} \cdot \mathrm{K}\end{array}$ & $\begin{array}{l}\Delta \mathrm{G}^{0}{ }_{298}, \\
\mathrm{~kJ} / \mathrm{mol}\end{array}$ & $\Delta \mathrm{a}$ & $\Delta \mathrm{b} \cdot 10^{3}$ & $\Delta \mathrm{c} \cdot 10^{-5}$ \\
\hline $\mathrm{TiO}_{2}+4 \mathrm{H}_{2} \mathrm{SO}_{4}=\mathrm{Ti}\left(\mathrm{SO}_{4}\right)_{2}+2\left(\mathrm{H}_{2} \mathrm{SO}_{4} \cdot \mathrm{H}_{2} \mathrm{O}\right)$ & -235.2 & $\begin{array}{l}-79.9 \\
\end{array}$ & -211.3 & -226.7 & -58 & 56.9 \\
\hline $\mathrm{TiO}_{2}+6\left(\mathrm{H}_{2} \mathrm{SO}_{4} \cdot \mathrm{H}_{2} \mathrm{O}\right)=\mathrm{Ti}\left(\mathrm{SO}_{4}\right)_{2}+4\left(\mathrm{H}_{2} \mathrm{SO}_{4} \cdot 2 \mathrm{H}_{2} \mathrm{O}\right)$ & -178.8 & -38.7 & -167.2 & -226.7 & -58 & 56.9 \\
\hline $\mathrm{TiO}_{2}+2 \mathrm{H}_{2} \mathrm{SO}_{4}=\mathrm{TiOSO}_{4}+\mathrm{H}_{2} \mathrm{SO}_{4} \cdot \mathrm{H}_{2} \mathrm{O}$ & -157.3 & 20.4 & -163.4 & -69.8 & -30 & 33.4 \\
\hline $\mathrm{TiO}_{2}+3\left(\mathrm{H}_{2} \mathrm{SO}_{4} \cdot \mathrm{H}_{2} \mathrm{O}\right)=\mathrm{TiOSO}_{4}+2\left(\mathrm{H}_{2} \mathrm{SO}_{4} \cdot 2 \mathrm{H}_{2} \mathrm{O}\right)$ & -129.1 & 41.0 & -141.3 & -69.8 & -30 & 33.4 \\
\hline
\end{tabular}
range of 298 to $510 \mathrm{~K}$. The upper temperature value is limited by the boiling point of $85 \mathrm{wt} . \%$ sulfuric

Table 1

Thermodynamic data of chemical transformations in $\mathrm{TiO}_{2}-\mathrm{SO}_{3}-\mathrm{H}_{2} \mathrm{O}$ system 
acid solution $\left(237^{\circ} \mathrm{C}\right)$. The choice of this temperature range allows disregarding the thermal effects of the processes of evaporation and decomposition of sulfuric acid with the formation of water and sulfur(VI) oxide. In addition, temperatures above $500 \mathrm{~K}$ are not used for sulfate-acid leaching of ilmenites. We neglected the thermal effects of the processes of water evaporation and an additional hydration of sulfuric acid due to the water which is formed during dissolution of $\mathrm{TiO}_{2}$ and does not leave the reaction mixture upon evaporation. The fact is that it is not possible to quantify the proportion of evaporated water that forms hydrates with sulfuric acid.

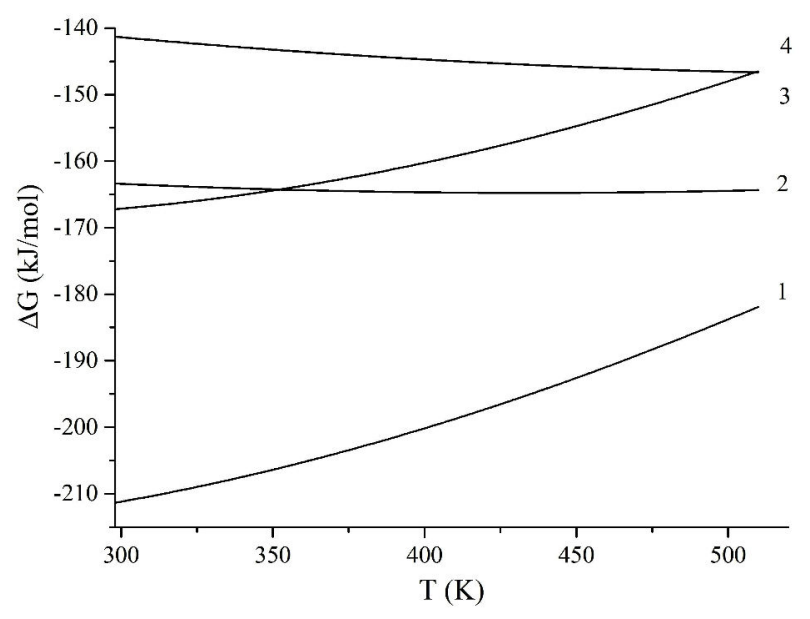

Fig. 1. Temperature dependences of changes in Gibbs energies: 1 -reaction (1); 2 - reaction (2); 3 - reaction (3); $4-$ reaction (4) and 5 - reaction (8)

The temperature dependences of the Gibbs energy for the formation reactions of $\mathrm{Ti}\left(\mathrm{SO}_{4}\right)_{2}$ (Eqs. (1) and (3) are characterized by positive angular coefficients. This can be explained by the fact that the reactions (1) and (3), unlike all other considered reactions, proceed with a decrease in entropy. Obviously, such values of $\Delta \mathrm{S}_{298}^{0}$ are associated with a higher degree of ordering of $\mathrm{Ti}\left(\mathrm{SO}_{4}\right)_{2}$ crystal than of $\mathrm{TiO}_{2}$ or $\mathrm{TiOSO}_{4}$.

The graphs of the $\Delta \mathrm{G}$ vs. $\mathrm{T}$ dependence monotonically decline with increasing the temperature for reactions (2) and (4). It is easily explained by a low degree of the crystal lattice ordering of the reaction product $\mathrm{TiOSO}_{4}$ as compared with $\mathrm{TiO}_{2}$.

The results of thermodynamic calculations of the interaction between rutile and sulfuric acid confirm the widespread opinion: titanium dioxide can be dissolved in concentrated sulfuric acid with the formation of tetravalent titanium salts. However, in cases of the dissolution of rutile, this process usually occurs slowly even in concentrated sulfuric acid at the temperature of its decomposition into $\mathrm{SO}_{3}$ and $\mathrm{H}_{2} \mathrm{O}$. A slow dissolution of rutile allows us to consider it as a chemically inert (ballast) component of the feedstock in the technological process of sulfateacid decomposition of altered ilmenites.

In our opinion, the deceleration of reactions (4)-(7) may be explained by the features of the properties of $\mathrm{Ti}(\mathrm{IV})$ cation and the crystal structure of rutile. It is known that Ti(IV) ions belong to the group of cations with a low degree of lability in terms of coordination chemistry. It is believed that a large positive charge of the titanium cation and its relatively small radius increase the activation energy of the substitution reaction. This reduces the rate of the exchange of intra-sphere ligands (oxygen ions in rutile) for other ligands from the solution (in our case, these are sulfate ions: its concentration is rather small in $\mathrm{H}_{2} \mathrm{SO}_{4}$ concentrated solutions).

Every titanium ion is surrounded by six oxygen ions located at the corners of the octahedron in the rutile crystal lattice. The octahedra are connected by two common edges and form chains parallel to the layers of the densest hexagonal packing. Although the tetragonal structure is typical of many other oxides, however it differs for rutile from «common» close-packed structures, like corundum. Whereas the layers of the densest packing of oxygen ions in the crystal structure of corundum are perpendicular to the triple axis and the layers are parallel to the faces of the octahedron in the spinel structure, the layers of the densest packing in rutile crystals are parallel to the main (quadruple) axis of the crystal structure. Obviously, a local widening of the crystal lattice will be required in the process of replacement of oxygen ions in such layers by larger anions of sulfuric acid. This process is associated with the additional energy consumption. The breaking of $-\mathrm{Ti}-\mathrm{O}-\mathrm{Ti}-$ bond without additional deformation of the crystal lattice is more beneficial in case of smaller anions (for instance, fluoride ions). In fact, according to the reference data, ionic radii vary in the following sequence: $\mathrm{SO}_{4}{ }^{2-} 0.295 \mathrm{~nm} ; \mathrm{O}^{2-} 0.136 \mathrm{~nm}$; and $\mathrm{F}^{-} 0.133 \mathrm{~nm}$. Therefore, it was of interest to consider the effect of fluorides on the effectiveness of the rutile sulfatization process.

Thermodynamic model of rutile dissolution by sulfate-fluoride method

We considered reactions that involve the formation of titanium(IV) sulfate and oxysulfate, sodium sulfate and sodium hydrogen sulfate, as well as hydrogen fluoride for modeling of the sulfate- 
fluoride leaching process with the addition of crystalline $\mathrm{NaF}$. The dissolution of rutile in sulfuric acid was accepted to proceed with the formation of two acid hydrates with $n=1$ and 2 , as in previous models:

a) for $100 \%$ sulfuric acid:

$\mathrm{TiO}_{2}+5 \mathrm{H}_{2} \mathrm{SO}_{4}+2 \mathrm{NaF}=$

$=\mathrm{Ti}\left(\mathrm{SO}_{4}\right)_{2}+\mathrm{Na}_{2} \mathrm{SO}_{4}+2\left(\mathrm{H}_{2} \mathrm{SO}_{4} \cdot \mathrm{H}_{2} \mathrm{O}\right)+2 \mathrm{HF} \uparrow$,

$\mathrm{TiO}_{2}+5 \mathrm{H}_{2} \mathrm{SO}_{4}+\mathrm{NaF}=$

$=\mathrm{Ti}\left(\mathrm{SO}_{4}\right)_{2}+\mathrm{NaHSO}_{4}+2\left(\mathrm{H}_{2} \mathrm{SO}_{4} \cdot \mathrm{H}_{2} \mathrm{O}\right)+\mathrm{HF} \uparrow$,

$\mathrm{TiO}_{2}+3 \mathrm{H}_{2} \mathrm{SO}_{4}+2 \mathrm{NaF}=$

$=\mathrm{TiOSO}_{4}+\mathrm{Na}_{2} \mathrm{SO}_{4}+\mathrm{H}_{2} \mathrm{SO}_{4} \cdot \mathrm{H}_{2} \mathrm{O}+2 \mathrm{HF} \uparrow$,

$\mathrm{TiO}_{2}+3 \mathrm{H}_{2} \mathrm{SO}_{4}+\mathrm{NaF}=$

$=\mathrm{TiOSO}_{4}+\mathrm{NaHSO}_{4}+\mathrm{H}_{2} \mathrm{SO}_{4} \cdot \mathrm{H}_{2} \mathrm{O}+\mathrm{HF} \uparrow$.

b) for $85 \%$ sulfuric acid:

$\mathrm{TiO}_{2}+8\left(\mathrm{H}_{2} \mathrm{SO}_{4} \cdot \mathrm{H}_{2} \mathrm{O}\right)+2 \mathrm{NaF}=$

$=\mathrm{Ti}\left(\mathrm{SO}_{4}\right)_{2}+\mathrm{Na}_{2} \mathrm{SO}_{4}+5\left(\mathrm{H}_{2} \mathrm{SO}_{4} \cdot 2 \mathrm{H}_{2} \mathrm{O}\right)+2 \mathrm{HF} \uparrow$,

$\mathrm{TiO}_{2}+8\left(\mathrm{H}_{2} \mathrm{SO}_{4} \cdot \mathrm{H}_{2} \mathrm{O}\right)+\mathrm{NaF}=$

$=\mathrm{Ti}\left(\mathrm{SO}_{4}\right)_{2}+\mathrm{NaHSO}_{4}+5\left(\mathrm{H}_{2} \mathrm{SO}_{4} \cdot 2 \mathrm{H}_{2} \mathrm{O}\right)+\mathrm{HF} \uparrow$,

$\mathrm{TiO}_{2}+5\left(\mathrm{H}_{2} \mathrm{SO}_{4} \cdot \mathrm{H}_{2} \mathrm{O}\right)+2 \mathrm{NaF}=$

$=\mathrm{TiOSO}_{4}+\mathrm{Na}_{2} \mathrm{SO}_{4}+3\left(\mathrm{H}_{2} \mathrm{SO}_{4} \cdot 2 \mathrm{H}_{2} \mathrm{O}\right)+2 \mathrm{HF} \uparrow$,

$\mathrm{TiO}_{2}+5\left(\mathrm{H}_{2} \mathrm{SO}_{4} \cdot \mathrm{H}_{2} \mathrm{O}\right)+\mathrm{NaF}=$

$=\mathrm{TiOSO}_{4}+\mathrm{NaHSO}_{4}+3\left(\mathrm{H}_{2} \mathrm{SO}_{4} \cdot 2 \mathrm{H}_{2} \mathrm{O}\right)+\mathrm{HF} \uparrow$.

The calculated values of $\Delta \mathrm{H}^{0}{ }_{298}, \Delta \mathrm{S}^{0}{ }_{298}, \Delta \mathrm{G}^{0}{ }_{298}$ as well as the coefficients $\Delta \mathrm{a}, \Delta \mathrm{b}$ and $\Delta \mathrm{c}$ in equations for the heat capacity change for reactions $(5)-(12)$ are summarized in Table 2. Figures 2 and 3 show the results of calculations of the change of Gibbs energy for these reactions for rutile in the temperature range of $298-510 \mathrm{~K}$.

The calculated values of Gibbs energy changes

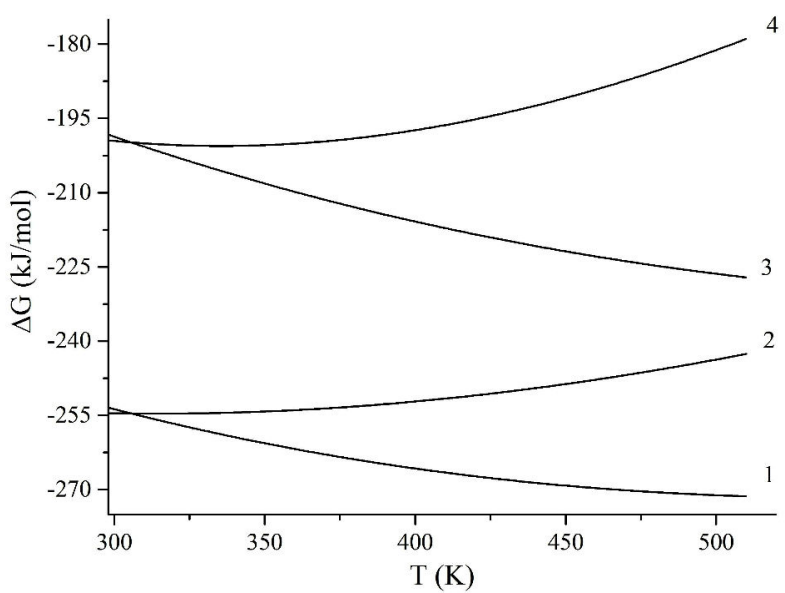

Fig. 2. Temperature dependences of Gibbs energies changes of $\mathrm{Ti}\left(\mathrm{SO}_{4}\right)_{2}$ formation reactions at dissolution of rutile in sulfuric acid with the participation of $\mathrm{NaF}$ activator reagent: 1 - reaction (5); 2 - reaction (6); 3 - reaction (9); $4-$ reaction $(10)$

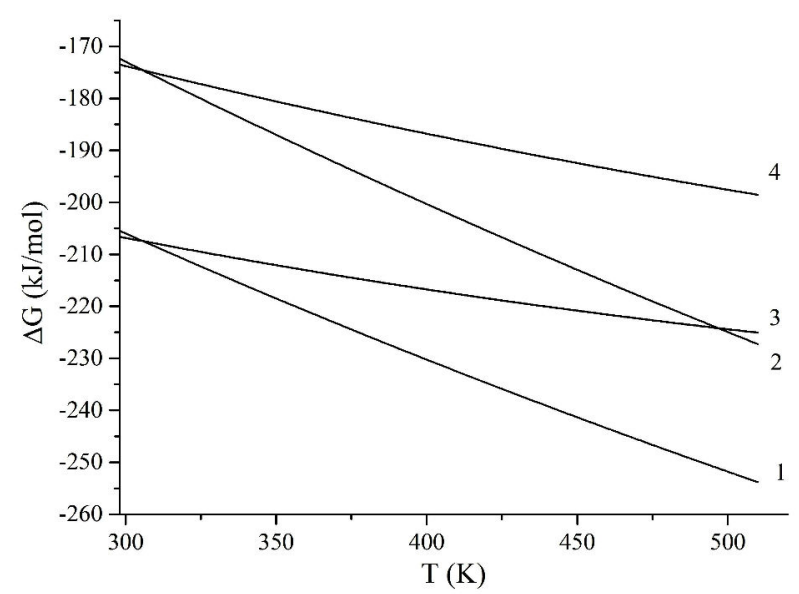

Fig. 3. Temperature dependences of Gibbs energies changes of $\mathrm{TiOSO}_{4}$ formation reactions at dissolution of rutile in sulfuric acid with the participation of $\mathrm{NaF}$ activator reagent: 1 - reaction (7); 2 - reaction (12); 3 - reaction (8); 4 - reaction (11)

Table 2

Thermodynamic data of chemical transformations in $\mathrm{TiO}_{2}-\mathrm{NaF}-\mathrm{SO}_{3}-\mathrm{H}_{2} \mathrm{O}$ system with formation of $\mathrm{Ti}\left(\mathrm{SO}_{4}\right)_{2}$ and $\mathrm{TiOSO}_{4}$

\begin{tabular}{|c|c|c|c|c|c|c|}
\hline Reaction & $\begin{array}{l}\Delta \mathrm{H}^{0}{ }_{298}, \\
\mathrm{~kJ} / \mathrm{mol}\end{array}$ & \begin{tabular}{|c|}
$\Delta \mathrm{S}^{0}{ }_{298}$ \\
$\mathrm{~kJ} / \mathrm{mol} \cdot \mathrm{K}$
\end{tabular} & $\begin{array}{l}\Delta \mathrm{G}^{0}{ }_{298}, \\
\mathrm{~kJ} / \mathrm{mol}\end{array}$ & $\Delta \mathrm{a}$ & $\Delta \mathrm{b} \cdot 10^{3}$ & $\Delta \mathrm{c} \cdot 10^{-5}$ \\
\hline $\mathrm{TiO}_{2}+5 \mathrm{H}_{2} \mathrm{SO}_{4}+2 \mathrm{NaF}=\mathrm{Ti}\left(\mathrm{SO}_{4}\right)_{2}+\mathrm{Na}_{2} \mathrm{SO}_{4}+2 \mathrm{HF} \uparrow+2\left(\mathrm{H}_{2} \mathrm{SO}_{4} \cdot \mathrm{H}_{2} \mathrm{O}\right)$ & -206.4 & 157.8 & -253.4 & -334.5 & 43 & 85.3 \\
\hline $\mathrm{TiO}_{2}+5 \mathrm{H}_{2} \mathrm{SO}_{4}+\mathrm{NaF}=\mathrm{Ti}\left(\mathrm{SO}_{4}\right)_{2}+\mathrm{NaHSO}_{4}+\mathrm{HF} \uparrow+2\left(\mathrm{H}_{2} \mathrm{SO}_{4} \cdot \mathrm{H}_{2} \mathrm{O}\right)$ & -251.2 & 11.2 & -254.6 & -317.9 & 55 & 82.8 \\
\hline $\mathrm{TiO}_{2}+3 \mathrm{H}_{2} \mathrm{SO}_{4}+2 \mathrm{NaF}=\mathrm{TiOSO}_{4}+\mathrm{Na}_{2} \mathrm{SO}_{4}+2 \mathrm{HF} \uparrow+\mathrm{H}_{2} \mathrm{SO}_{4} \cdot \mathrm{H}_{2} \mathrm{O}$ & -128.5 & 258.1 & -205.4 & -177.6 & 71 & 61.8 \\
\hline $\mathrm{TiO}_{2}+3 \mathrm{H}_{2} \mathrm{SO}_{4}+\mathrm{NaF}=\mathrm{TiOSO}_{4}+\mathrm{NaHSO}_{4}+\mathrm{HF} \uparrow+\mathrm{H}_{2} \mathrm{SO}_{4} \cdot \mathrm{H}_{2} \mathrm{O}$ & -173.4 & 111.5 & -206.6 & -161.0 & 84 & 59.4 \\
\hline $\mathrm{TiO}_{2}+8\left(\mathrm{H}_{2} \mathrm{SO}_{4} \cdot \mathrm{H}_{2} \mathrm{O}\right)+2 \mathrm{NaF}=\mathrm{Ti}\left(\mathrm{SO}_{4}\right)_{2}+\mathrm{Na}_{2} \mathrm{SO}_{4}+2 \mathrm{HF} \uparrow+5\left(\mathrm{H}_{2} \mathrm{SO}_{4} \cdot 2 \mathrm{H}_{2} \mathrm{O}\right)$ & -135.9 & 209.3 & -198.3 & -334.5 & 43 & 85.3 \\
\hline $\mathrm{TiO}_{2}+8\left(\mathrm{H}_{2} \mathrm{SO}_{4} \cdot \mathrm{H}_{2} \mathrm{O}\right)+\mathrm{NaF}=\mathrm{Ti}\left(\mathrm{SO}_{4}\right)_{2}+\mathrm{NaHSO}_{4}+\mathrm{HF} \uparrow+5\left(\mathrm{H}_{2} \mathrm{SO}_{4} \cdot 2 \mathrm{H}_{2} \mathrm{O}\right)$ & -180.7 & 62.7 & -199.4 & -631.7 & 55 & 82.8 \\
\hline $\mathrm{TiO}_{2}+5\left(\mathrm{H}_{2} \mathrm{SO}_{4} \cdot \mathrm{H}_{2} \mathrm{O}\right)+2 \mathrm{NaF}=\mathrm{TiOSO}_{4}+\mathrm{Na}_{2} \mathrm{SO}_{4}+2 \mathrm{HF} \uparrow+3\left(\mathrm{H}_{2} \mathrm{SO}_{4} \cdot 2 \mathrm{H}_{2} \mathrm{O}\right)$ & -86.2 & 289.0 & -172.4 & -177.6 & 71 & 61.8 \\
\hline $\mathrm{TiO}_{2}+5\left(\mathrm{H}_{2} \mathrm{SO}_{4} \cdot \mathrm{H}_{2} \mathrm{O}\right)+\mathrm{NaF}=\mathrm{TiOSO}_{4}+\mathrm{NaHSO}_{4}+\mathrm{HF} \uparrow+3\left(\mathrm{H}_{2} \mathrm{SO}_{4} \cdot 2 \mathrm{H}_{2} \mathrm{O}\right)$ & -131.1 & 142.4 & -173.5 & -161.0 & 84 & 59.4 \\
\hline
\end{tabular}


indicate that the reactions $(5)-(12)$ are thermodynamically possible: the Gibbs energy changes are negative in the whole temperature range. The addition of sodium fluoride leads to a decrease in the standard Gibbs energy by about $30 \mathrm{~kJ} / \mathrm{mol}$, and this difference is almost doubled with increasing temperature up to $500 \mathrm{~K}$. The only exceptions are reactions (6) and (10). The temperature dependences of the Gibbs energies for these reactions pass through a weakly pronounced minimum. The $\Delta \mathrm{S}_{298}^{0}$ values for these reactions are positive, although, an order of magnitude is less than for other reactions. Therefore, the positive angular coefficients of the dependences $\Delta \mathrm{G}$ vs. $\mathrm{T}$ in this case can be explained by a change in the heat capacity of the participants in the chemical transformation, which is described by the last term of the Temkin-Schwartzman equation.

The temperature dependences of the Gibbs energies are characterized by relatively large negative angular coefficients for all other reactions involving the presence of $\mathrm{NaF}$. This can be explained by the following fact: these reactions proceed with a large increase in entropy due to the formation of gaseous HF. If we take into account that the removal of gaseous HF from the reaction zone displaces its equilibrium to the right (according to the Le Chatelier principle), then it should be concluded that the rutile can be completely dissolved. In addition, it should be noted that reactions $(6),(8),(10)$ and (12) reduce the molar ratio of $\mathrm{NaF} / \mathrm{TiO}_{2}$ from 2 to 1 . However, the complete conversion of $\mathrm{TiO}_{2}$ will require the use of an excess of fluorides in the reaction mixture because of possible losses of hydrogen fluoride during the leaching process.

In conclusion, it should be noted that the thermodynamic calculations considered above for the $\mathrm{TiO}_{2}-\mathrm{NaF}-\mathrm{SO}_{3}-\mathrm{H}_{2} \mathrm{O}$ system were performed without taking into account the formation of titanium(IV) fluoride compounds. Table 3 and Figure 4 show the results of calculations of the thermodynamic possibility of the reactions of rutile dissolution with the formation of $\mathrm{TiF}_{4}$ and $\mathrm{TiOF}_{2}$.

$\mathrm{TiO}_{2}+4 \mathrm{H}_{2} \mathrm{SO}_{4}+4 \mathrm{NaF}=$

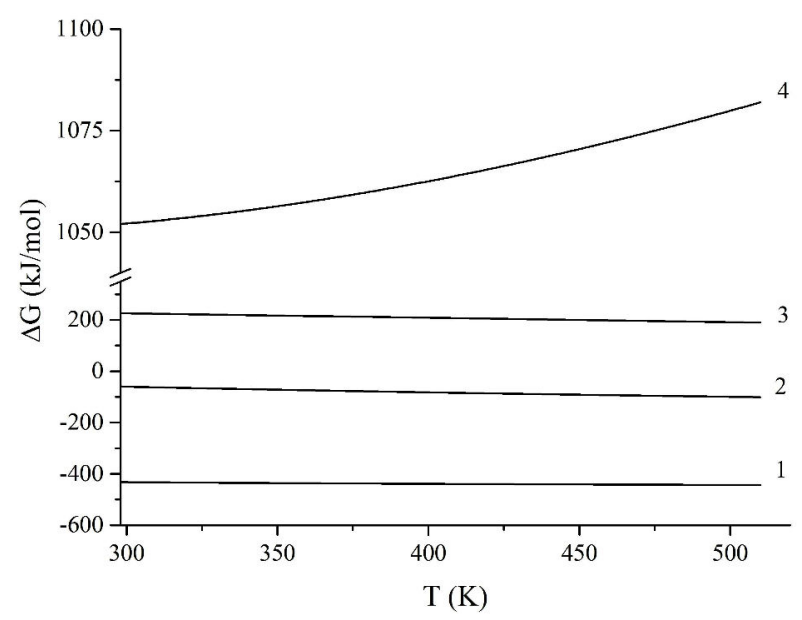

Fig. 4. Temperature dependences of Gibbs energies changes of formation and decomposition reactions of $\mathrm{TiF}_{4}$ and $\mathrm{TiOF}_{2}$ :

1 - reaction (16); 2 - reaction (15); 3 - reaction (14);

$$
4 \text { - reaction (13) }
$$

$=\mathrm{TiF}_{4}+2 \mathrm{Na}_{2} \mathrm{SO}_{4}+2\left(\mathrm{H}_{2} \mathrm{SO}_{4} \cdot \mathrm{H}_{2} \mathrm{O}\right)$,

$\mathrm{TiO}_{2}+2 \mathrm{H}_{2} \mathrm{SO}_{4}+2 \mathrm{NaF}=$

$=\mathrm{TiOF}_{2}+\mathrm{Na}_{2} \mathrm{SO}_{4}+\left(\mathrm{H}_{2} \mathrm{SO}_{4} \cdot \mathrm{H}_{2} \mathrm{O}\right)$.

Titanium fluorides and oxyfluorides in the temperature range under consideration, as well as $\mathrm{HF}$, are in a gaseous state. Considering these substances in the standard state in the form of a gas, one should take into account the possibility of its decomposition, for example, by the following reactions:

$\mathrm{TiF}_{4}+2 \mathrm{H}_{2} \mathrm{SO}_{4}=\mathrm{Ti}\left(\mathrm{SO}_{4}\right)_{2}+4 \mathrm{HF}$

$\mathrm{TiOF}_{2}+\mathrm{H}_{2} \mathrm{SO}_{4}=\mathrm{TiOSO}_{4}+2 \mathrm{HF}$.

The calculated changes of Gibbs energy show that reactions (13) and (14) are thermodynamically impossible, since the values are higher than zero. On the contrary, reactions (15) and (16) in the whole temperature range under study are characterized by negative $\Delta \mathrm{G}$ values, which additionally confirms the impossibility of the formation of $\mathrm{TiF}_{4}$ and $\mathrm{TiOF}_{2}$ in

Table 3

\begin{tabular}{|c|c|c|c|c|c|c|}
\hline Reaction & $\begin{array}{l}\Delta \mathrm{H}^{0}{ }_{298}, \\
\mathrm{~kJ} / \mathrm{mol}\end{array}$ & $\begin{array}{c}\Delta \mathrm{S}_{298,}^{0} \\
\mathrm{~kJ} / \mathrm{mol} \cdot \mathrm{K}\end{array}$ & $\begin{array}{l}\Delta \mathrm{G}_{298}^{0}, \\
\mathrm{~kJ} / \mathrm{mol}\end{array}$ & $\Delta \mathrm{a}$ & $\Delta \mathrm{b} \cdot 10^{3}$ & $\Delta \mathrm{c} \cdot 10^{-5}$ \\
\hline $\mathrm{TiO}_{2}+4 \mathrm{H}_{2} \mathrm{SO}_{4}+4 \mathrm{NaF}=\mathrm{TiF}_{4}+2 \mathrm{Na}_{2} \mathrm{SO}_{4}+2\left(\mathrm{H}_{2} \mathrm{SO}_{4} \cdot \mathrm{H}_{2} \mathrm{O}\right)$ & 1033.2 & -63.2 & 1052.0 & -393.0 & 158 & 85.9 \\
\hline $\mathrm{TiO}_{2}+2 \mathrm{H}_{2} \mathrm{SO}_{4}+2 \mathrm{NaF}=\mathrm{TiOF}_{2}+\mathrm{Na}_{2} \mathrm{SO}_{4}+\left(\mathrm{H}_{2} \mathrm{SO}_{4} \cdot \mathrm{H}_{2} \mathrm{O}\right)$ & 280.0 & 179.1 & 226.6 & -224.5 & 82 & 36.1 \\
\hline $\mathrm{TiF}_{4}+2 \mathrm{H}_{2} \mathrm{SO}_{4}=\mathrm{Ti}\left(\mathrm{SO}_{4}\right)_{2}+4 \mathrm{HF}$ & 138.2 & 247.1 & -59.8 & -206.2 & -43 & 51.3 \\
\hline $\mathrm{TiOF}_{2}+\mathrm{H}_{2} \mathrm{SO}_{4}=\mathrm{TiOSO}_{4}+2 \mathrm{HF}$ & -408.5 & 78.9 & -432.0 & -103.1 & -21 & 25.6 \\
\hline
\end{tabular}


under investigated conditions. Thus, the consideration of the thermodynamic equilibrium in the $\mathrm{TiO}_{2}-\mathrm{NaF}-\mathrm{SO}_{3}-\mathrm{H}_{2} \mathrm{O}$ system without taking into account the formation of fluoride and oxyfluoride titanium(IV) compounds is completely justified and does not contradict the above conclusions.

\section{Conclusions}

The rutile can spontaneously dissolve in $\mathrm{H}_{2} \mathrm{SO}_{4}$ solutions with the formation of salts $\mathrm{Ti}\left(\mathrm{SO}_{4}\right)_{2}$ and $\mathrm{TiOSO}_{4}$ as was shown by thermodynamic analysis of the leaching of titanium in the $\mathrm{TiO}_{2}-\mathrm{SO}_{3}-\mathrm{H}_{2} \mathrm{O}$ system. At the same time, the experimentally proven inhibition effect of such reactions forces to consider rutile as an inert (ballast) component of titaniumbearing raw materials. In our opinion, the kinetic decelaration of the reactions of rutile dissolution in sulfuric acid should be explained by the features of Ti(IV) cation properties and the rutile crystal structure. A low degree of lability of Ti(IV) cation increases the activation energy of substitution reactions in its coordination sphere and it reduces the rate of exchange of oxygen ions by sulfate ions. It should be noted that the concentration of sulfate ions in concentrated $\mathrm{H}_{2} \mathrm{SO}_{4}$ solutions is rather small and it further reduces the rate of substitution reaction. In addition, it should be remembered that the size of sulfate ions is more than two times larger than oxygen ions. Therefore, the exchange of oxygen ions by sulfate ions in the rutile lattice should be inhibited by the processes of local expansion of the rutile crystal lattice. The breaking of $\mathrm{Ti}-\mathrm{O}-\mathrm{Ti}$ bonds without additional strains of the crystal lattice is suggested to be more beneficial when using smaller anions, among which fluoride ions can be considered. The thermodynamic analysis of sulfate-fluoride leaching of titanium confirmed an additional decrease in the Gibbs energy values of the reaction of rutile dissolution in sulfuric acid in the presence of fluoride ions. A reaction mechanism was proposed that describes the interaction of rutile with sulfuric acid. The mechanism involves the stage of breaking of $\mathrm{Ti}-\mathrm{O}-\mathrm{Ti}$ bonds on the surface of rutile due to the replacement of oxygen ions by fluoride ions and the stage of sulfuric acid decomposition of titanium dioxide on the sites of surface «defects» in the rutile lattice.

\section{REFERENCES}

1. Proizvodstvo dvuokisi titana pigmentnoi sul'fatnym sposobom / V.N. Skomoroha, V.G. Zarechennyi, I.P. Vorob'eva, S.V. Vakal. - Summy: ATZT «Arsenal-Press», 2002. - 204 p.
2. Vliyanie mekhanicheskoi aktivatsii il'menita Malyshevskogo mestorozhdeniya na ego fazovyi sostav i skorost' sul'fatizatsii / Kalashnikov Y.V., Nikolenko N.V., Kachalova A.S., Dubenko A.V., Abramova A.N. // Voprosy Khimii i Khimicheskoi Tekhnologii. - 2015. - No. 5. - P.63-71.

3. Sernokislotnoe razlozhenie izmenennogo il'menita / Nikolenko N.V., Dubenko A.V., Suschinskii A.D., Kalashnikov Y.V. // Voprosy Khimii i Khimicheskoi Tekhnologii. - 2016. No. 4. - P.55-62.

4. Karelin V.A., Karelin A.I. Ftoridnaya tekhnologiya pererabotki kontsentratov redkikh metallov. - Tomsk: NTL, 2004. $-184 \mathrm{p}$.

5. Karelin V.A., Kameneva O.V. Ftoridnyi metod pererabotki rutilovogo kontsentrata // Izvestiya Tomskogo Politekhnicheskogo Universiteta. - 2006. - Vol.309. - No. 3. - P.94-99.

6. Hansen D.A., Traut D.E. The kinetics of leaching rock ilmenite with hydrofluoric acid // JOM. - 1989. - Vol.41. P.34-36.

7. Gordienko P.S., Dostovalov V.A., Pashnina E.V. Hydrofluoride method of complex processing of titaniumcontaining raw materials // Solid State Phenom. - 2017. Vol.265. - P.542-547.

8. Maslennikova I.G. Influence of the amount of ammonium hydrogen difluoride on the degree of fluorination of mineral raw materials // Russ. J. Appl. Chem. - 2009. - Vol.82. - No. 8. P.1333-1337.

9. Laptash N., Maslennikova I. Fluoride processing of titanium-containing minerals // Adv. Mater. Phys. Chem. - 2012. - Vol.2. - P.21-24.

10. Thermodynamic and kinetic analyses of the decomposition of iron molybdate with soda ash solutions / Nikolenko N.V., Samchilev I.S., Kalashnikova A.N., Ananchenko B.A. // Russ. J. Appl. Chem. - 2015. - Vol.88. - No. 2. - P.208-215.

11. The calculation of the thermodynamic equilibrium in $\mathrm{Fe}^{3+} / \mathrm{MoO}_{4}{ }^{2-} / \mathrm{H}^{+}\left(\mathrm{OH}^{-}\right) / \mathrm{H}_{2} \mathrm{O}$ system and determination of reasonable conditions for iron molybdate deposition / Nikolenko N.V., Kostynyuk A.O., Kalashnikov Yu.V., Cheremis E.A. // Russ. J. Appl. Chem. - 2012. - Vol.85. - No. 12. - P.18141819.

12. Chemical precipitation of iron(III) molybdate + molybdenum trioxide mixtures through continuous crystallization / Nikolenko M.V., Kostynyuk A.O., Goutenoire F., Kalashnikov Yu.V. // Inorg. Mater. - 2014. - Vol.50. - No. 11. - P.1140-1145.

13. Temperaturnyi optimum protsessa sernokislotnogo razlozheniya izmenennogo il'menita / Nikolenko N.V., Dubenko A.V., Vashkevich E.Yu., Dmitrikova L.V. // Voprosy Khimii i Khimicheskoi Tekhnologii. - 2018. - No. 3. - P.70-78.

14. Dean J.A. Lange's Handbook of Chemistry (15th edition). - McGraw-Hill, 1999.

Received 24.03.2020 


\section{ТЕРМОДИНАМІЧНЕ МОДЕЛЮВАННЯ СУЛЬФАТНОКИСЛОТНОГО І СУЛЬФАТНО- ФТОРИДНОГО ВИЛУГОВУВАННЯ ТИТАНУ}

\section{А.В. Дубенко, М.В. Ніколенко, О.Б. Веліченко, О.Д. Сущинський}

Вивчена термодинамічна рівновага в системах $\mathrm{TiO}_{2}-\mathrm{SO}_{3}-\mathrm{H}_{2} \mathrm{O}$ i $\mathrm{TiO}_{2}-\mathrm{NaF}-\mathrm{SO}_{3}-\mathrm{H}_{2} \mathrm{O}$. Показано, що рутил може самочинно розчинятися в розчинах сульфатної кислоти. Однак, через загальмованість таких реакиій рутил розглядається як інертний компонент титанвмісної сировини. Кінетичні ускладнення реакиї сульфатнокислотного розчинення рутилу пояснені лабільністю катіонів Ti(IV) і особливостями кристалічної структури рутилу. Припущено, що розрив зв'язків Ti-O-Ti без додаткових деформацій кристалічної решітки більш вигідний при використанні менших за розміром аніонів, 6 якості яких можна використовувати фторид-іони. Термодинамічний аналіз сульфатно-фторидного вилуговування титану підтвердив додаткове зниження енергії Гіббса для реакції розчинення рутилу в сульфатній кислоті в присутності фторидіонів. Запропоновано механізм реакиії взаємодії рутилу з сульфатною кислотою, що включає стадію заміщення іонів кисню на поверхні рутилу фторид-іонами і стадію сульфатнокислотного розкладання діоксиду титану по місиях «дефектів» на поверхні рутилу.

Ключові слова: термодинамічне моделювання, сульфатна кислота, фторид-іони, змінений ільменіт, рутил.

\section{THERMODYNAMIC MODELING OF SULFATE-ACID AND SULFATE-FLUORIDE LEACHING OF TITANIUM}

\section{A.V. Dubenko ${ }^{a}$, N.V. Nikolenko ${ }^{a,}$ ", A.B. Velichenko ${ }^{a}$,} A.D. Suschinskii ${ }^{b}$

a Ukrainian State University of Chemical Technology, Dnipro, Ukraine

\section{b Zaporizhzhia National University, Zaporizhzhia, Ukraine}

* e-mail: n_nikolenko@ukr.net

The thermodynamic equilibrium in $\mathrm{TiO}_{2}-\mathrm{SO}_{3}-\mathrm{H}_{2} \mathrm{O}$ and $\mathrm{TiO}_{2}-\mathrm{NaF}-\mathrm{SO}_{3}-\mathrm{H}_{2} \mathrm{O}$ systems is studied. It is shown that rutile can spontaneously dissolve in sulfuric acid solutions. However, rutile is considered as an inert component of the titanium-bearing raw material due to the inhibition of such reactions. The kinetic deceleration of rutile dissolution in sulfuric acid is explained by the lability of Ti(IV) cations and the specific features of the rutile crystal structure. The breaking of Ti-O-Ti bonds without additional deformations of the crystal lattice is suggested to be more beneficial when using smaller anions; thus, fluoride ions can be used to this end. The thermodynamic analysis of sulfate-fluoride leaching of titanium confirms an additional decrease in Gibbs energy values for the dissolution of rutile in sulfuric acid in the presence of fluoride ions. A reaction mechanism is proposed for the interaction of rutile with sulfuric acid. The mechanism includes the stage of substitution of oxygen ions on the rutile surface by fluoride ions and the stage of sulfate-acid decomposition of titanium dioxide in places of «defects» of the rutile surface.

Keywords: thermodynamic modeling; sulfuric acid; fluoride ions; altered ilmenite; rutile.

\section{REFERENCES}

1. Skomoroha V.N., Zarechennyi V.G., Vorob'eva I.P., Vakal S.V., Proizvodstvo dvuokisi titana pigmentnoi sul'fatnym sposobom [Production of pigment titanium dioxide by the sulfate method]. ATZT Arsenal-Press Publishers, Sumy, 2002. 204 p. (in Russian).

2. Kalashnykov Y.V., Nikolenko N.V., Kachalova A.S., Dubenko A.V., Abramova A.N. Vliyanie mekhanicheskoi aktivatsii il'menita Malyshevskogo mestorozhdeniya na ego fazovyi sostav i skorost' sul'fatizatsii [Effect of mechanical activation of Malyshevsky ilmenite on its phase composition and leaching rate]. Voprosy Khimii i Khimicheskoi Tekhnologii, 2015, no. 5, pp. 6371. (in Russian).

3. Nikolenko N.V., Dubenko A.V., Suschinskii A.D., Kalashnikov Y.V. Sernokislotnoe razlozhenie izmenennogo il'menita [Decomposition of altered ilmenite by sulphuric acid]. Voprosy Khimii i Khimicheskoi Tekhnologii, 2016, no. 4, pp. 5562. (in Russian).

4. Karelin V.A., Karelin A.I., Ftoridnaya tekhnologiya pererabotki kontsentratov redkikh metallov [Fluoride technology for processing rare metal concentrates]. NTL Publishers, Tomsk, 2004. 184 p. (in Russian).

5. Karelin V.A., Kameneva O.V. Ftoridnyi metod pererabotki rutilovogo kontsentrata [Rutile concentrate fluoride processing method]. Izvestiya Tomskogo Politekhnicheskogo Universiteta, 2006, vol. 309, no. 3, pp. 94-99. (in Russian).

6. Hansen D.A., Traut D.E. The kinetics of leaching rock ilmenite with hydrofluoric acid. JOM Journal of the Minerals Metals and Materials Society, 1989, vol. 41, pp. 34-36.

7. Gordienko P.S., Dostovalov V.A., Pashnina E.V. Hydrofluoride method of complex processing of titaniumcontaining raw materials. Solid State Phenomena, 2017, vol. 265, pp. 542-547.

8. Maslennikova I.G. Influence of the amount of ammonium hydrogen difluoride on the degree of fluorination of mineral raw materials. Russian Journal of Applied Chemistry, 2009, vol. 82, pp. 1333-1337.

9. Laptash N., Maslennikova I. Fluoride processing of titanium-containing minerals. Advances in Materials Physics and Chemistry, 2012, vol. 2, pp. 21-24.

10. Nikolenko N.V., Samchilev I.S., Kalashnikova A.N., Ananchenko B.A. Thermodynamic and kinetic analyses of the decomposition of iron molybdate with soda ash solutions. Russian Journal of Applied Chemistry, 2015, vol. 88, pp. 208-215.

11. Nikolenko N.V., Kosynyuk A.O., Kalashnikov Yu.V., Cheremis E.A. The calculation of the thermodynamic equilibrium in $\mathrm{Fe}^{3+} / \mathrm{MoO}_{4}{ }^{2-} / \mathrm{H}^{+}\left(\mathrm{OH}^{-}\right) / \mathrm{H}_{2} \mathrm{O}$ system and determination of the reasonable conditions for iron molybdate deposition. Russian Journal of Applied Chemistry, 2012, vol. 85, pp. 1814-1819.

12. Nikolenko M.V., Kostynyuk A.O., Goutenoire F., Kalashnikov Yu.V. Chemical precipitation of iron(III) molybdate + molybdenum trioxide mixtures through continuous crystallization. Inorganic Materials, 2014, vol. 50, pp. 1140-1145.

13. Nikolenko N.V., Dubenko A.V., Vashkevich E.Yu., Dmitrikova L.V. Temperaturnyi optimum protsessa sernokislotnogo razlozheniya izmenennogo il'menita [Temperature optimum of the process of the dissolution of altered ilmenite in sulfuric acid]. Voprosy Khimii i Khimicheskoi Tekhnologii, 2018, no. 3, pp. 70-78. (in Russian).

14. Dean J.A., Lange's handbook of chemistry (15th edition). McGraw-Hill, 1999. 